\title{
NELFA Gene
}

National Cancer Institute

\section{Source}

National Cancer Institute. NELFA Gene. NCI Thesaurus. Code C75438.

This gene plays a role in the negative regulation of transcription elongation. 